DOI https://doi.org/10.30525/978-9934-26-039-1-38

\title{
СЛОВОСКЛАДАННЯ ЯК ПРОДУКТИВНИЙ СПОСІБ ТВОРЕННЯ РЕЛІГІЙНОЇ ЛЕКСИКИ
}

\author{
Бойчук М. I. \\ здобувач кафедри англійської філології \\ Львівського національного університету імені Івана Франка \\ м. Львів, Украӥна
}

Словоскладання - один з найпродуктивніших способів творення слів. Даний процес являє поєднання двох або більше основ 3 можливими подальшими змінами новоутвореного композита. Складне слово композит - розглядається лінгвістами як «самостійна граматично i семантично єдина лексична величина, яка є частиною словникового запасу мови і в реченні може виступати в ролі головного чи другорядного члена речення» $[7,96]$. У композиційні відносини можуть вступати між собою найрізноманітніші частини мови, якщо для створення якогось складного слова є логічне обгрунтування [4, с. 94]. Складні слова характеризуються у мовленні своєю цільністю. Під цільністю розуміється нероздільність, неподільність, неможливість поділу на частини і розміщення між ними інших елементів (одиниць) мови.

Розглядаючи фонетичну складову складних слів відслідковуємо, що більшість складних іменників має наголос на першому складі: bellman ['belman], breastplate ['brestplert], candlestick ['kændəlstik], chapelman

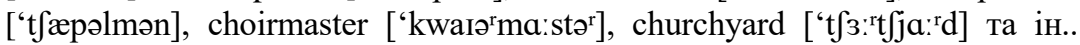
Проте, трапляються випадки коли обидва компоненти зберігають свої наголоси, це може бути основний i другорядний або два основних наголоси: bedehouse [' bid haos], Christmastime ['krısməs, tarm], cross-bearer ['kros,beərər], lampstand ['læmp, stænd] miracle-worker ['mırəkəl 'wз:kə],

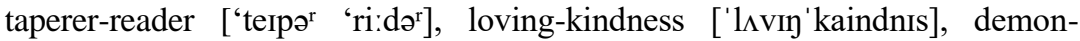
possessed ['di:mənpə’zest] та ін..

Структурна цілісність складних слів також $\epsilon$ показовою для відмежування їх від словосполучень. Елементи складного слова не можуть бути переставлені іншим чином і зберігати теж значення, тоді як для вільних чи стійких словосполучень це цілком можливо. Наприклад, вільне словосполучення a religious man допускає варіанти This is a religious man або This man is religious. У першому випадку зв'язок $\epsilon$ атрибутивним, у другому - предикативним, проте речення синонімічні. 
Для складного слова a poppyhead (a carved ornament, esp one used on the top of the end of a pew or bench in Gothic church architecture) такі зміни неможливі.

Складні слова є багатоаспектними одиницями. Вони можуть бути класифіковані за різними принципами і розглядатися з різних точок зору. Крім того, складні слова часто аналізуються за граматичними моделям, тісний зв'язок з граматикою (зокрема, з синтаксисом) підкреслюється при розподілі всіх складних слів на синтаксичні та асинтаксичні. Л.Блумфілд відносить до перших такі складні слова, в яких порядок послідовності компонентів збігається 3 порядком слів в синтаксичних словосполученнях (gravestone - могильний камінь), до других - такі складні слова, в яких компоненти знаходяться в комбінаціях, неможливих для синтаксису даної мови (manes worship - боготворіння померлих) [3, с. 253].

3 урахування структури компонентів складних слів ми виділяємо таку структурну класифікацію:

a) складні слова, що складаються з простих основ (headscarf «платок», hell-gate «ворота пекла», idol-god «ідол, кумир, (язичницький) божок»); б) складні слова, в яких один із компонентів $є$ похідною основою (iconpainter «іконописець», miracle-worker «чудотворець», oath breaker «клятвопорушник»); в) складні слова, один 3 компонентів яких скорочення (TV evangelist «телевізійний проповідник»); г) складні слова, один з компонентів яких - складна основа (high churchman «прихильник Високої церкви»).

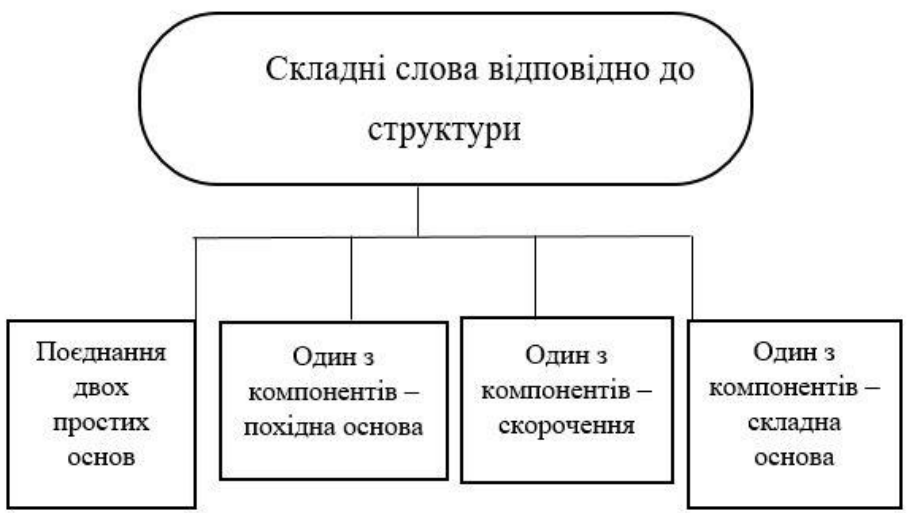

Рисунок 1. 
3 точки зору способів, за допомогою яких з'єднуються компоненти I.B. Арнольд виділяє наступні типи складних слів :

- слова, утворені простим складанням компонентів (нейтральний тип) в певному порядку, в якому мотивуючі слова поєднуються за синтаксичними правилами англійської мови і відповідають порядку слів у вільних поєднаннях, побудованих за правилами синтаксису: God-seeker, icon-painter, church-robber;

- складні слова, компоненти яких з'єднані сполучним елементом сполучними голосними -о-, -i-aбо сполучною приголосною -s(морфологічний тип): wandsman, synodsman, iconomania. Даний спосіб словосладання був розвинений у давньоанглійській, але в сучасній мові зустрічається порівняно рідко: handicraft, handiwork, tradesman, crowsfeet, Anglo-Saxon;

- складні слова третього типу представляють собою відокремлені синтагми, що зберегли сполучні основи службових слів: man of prayer, curate-in-charge. Такий тип словоскладання називається синтаксичним.

Залежно від того, виведені чи невиведені значення і граматичні функції складного слова $з$ його компонентів виділяються ендоцентричні та екзоцентричні складні слова. Bauer $[5$, с. 326] до ендоцентричних відносить складні слова, які складаються з головного та залежного слова (або декількох залежних), де значення семантично головного є гіпонімом значення всієї сполуки. Значення та граматичні функції ендоцентричних складних слів виводяться з їх компонентів. Наприклад, модель $\mathrm{Adj}+\mathrm{N}=$ $\mathrm{N} \epsilon$ ендоцентричною, оскільки по ній утворюються складні іменники, тобто частина мови, представлена другим компонентом. До ендоцентричних можна також віднести наступні моделі, які ми виявили під час аналізу словника релігійної лексики $\mathrm{V}+\mathrm{N}=\mathrm{N}$, Part I $+\mathrm{N}=\mathrm{N}$, Ger $+\mathrm{N}=\mathrm{N}, \mathrm{N}+\mathrm{N}=\mathrm{N}$. Приклади складних слів: a store-house, a blessing boon, a hell-gate.

До екзоцентричних складних слів відносяться слова, значення i граматичні функції яких не виводяться з їх компонентів. Bauer $[5,42]$ стверджує, що екзоцентричні складні слова позначають те, що не $\epsilon$ підкласом жодного з елементів у сполуці, тобто вони не є гіпонімами жодного зі своїх елементів. У екзоцентричних складних словах цікавим $\epsilon$ те, що вони можуть використовувати неправильний маркер множини або суфікс множини -s у головному слові [6]. Наприклад, bottomless gulf первозданний хаос, значення bottomless - безмежний, gulf - залив, бухта, прірва. Модель Participle $+\mathrm{N}=\operatorname{Adj} \epsilon$ екзоцентричною, оскільки по ній утворюються складні прикметники, тобто частина мови, не представлена компонентами складного слова. 
Аналізуючи словник релігійної лексики в англійській мові прослідковуємо класифікацію складних слів в залежності від типу основи. Складні слова діляться на власне складні та складнопохідні. Складнопохідні слова (angel-faced, dome-shaped, cross-shaped) відрізняються від власне складних слів словотвірною основою, а також природою другого елементу. Двома частинами складного слова angel-faced $є$ суфікс -ed зі значенням «having» і основа, утворена від вільного поєднання angel face, члени якого втрачають граматичну самостійність і скорочуються до одного компонента слова - його словотвірної основи. 3 іншого боку, подібні слова можна розглядати як псевдоскладні або як особливу групу похідних, так як вони формуються на базі вільного словосполучення, до якого приєднується суфікс.

\section{Література:}

1. Азаров А. А. Большой англо-русский словарь религиозной лексики. Comprehensive English-Russian Dictionary of Religious Terminology. Москва, 2004. 808 с.

2. Арнольд И.В. Лексикология современного английского языка: учеб. пособие. Москва, 2012. 376 с.

3. Блумфилд Л. Язык. Москва, 1968. 606 с.

4. Наконечна Г.В. Словоскладання як один із найпоширеніших способів словотвору німецької мови. Кіровоград : РВВ КДПУ ім. В. Винниченка, 2009. 430с.

5. Bauer L. Introducing linguistic morphology (2nd ed.). Edinburgh, 2003. $366 \mathrm{p}$.

6. O'Grady W., Dobrovolsky M., Katamba F. Contemporary linguistics: An introduction. London,1996. 776 p.

7. Ortner L. Deutsche Wortbildung: Typen und Tendenzen in der gegenwartssprache. Berlin, 1991. $863 \mathrm{~S}$. 